\title{
Numerical Analysis in Dengkeng River Using Nays2DFlood
}

\author{
Amanatullah Savitri*, Hary Budieny, Fajar Bagaskara, Fitri Maya Lestari \\ Department of Civil Engineering, Faculty of Engineering, Diponegoro University, Semarang, Indonesia
}

Received February 25, 2020; Revised June 24, 2020; Accepted July 7, 2020

Copyright $\odot 2020$ by authors, all rights reserved. Authors agree that this article remains permanently open access under the terms of the Creative Commons Attribution License 4.0 International License

\begin{abstract}
Flooding is one of the disasters that occur in almost all regions of Indonesia every year. The National Disaster Management Agency of Indonesia (BNPB) recorded 1,999 flood disasters since the beginning of 2018 until October 2018 causing 4,157 people dying and disappearing. Dengkeng River is a tributary of the Bengawan Solo River that experiences flooding problems when the rainy season arrives. Previous studies have produced one-dimensional river (1D) which does not provide detailed information of flooding modelling and analyzed sedimentation rates from secondary data. However, there is rare research and detailed observation on this subject in this area. Therefore, flood simulation models are required to identify flood-prone areas. In this study, a two-dimensional (2D) river model using the International River Interface Cooperative (iRIC) Nays2DFlood software from Japan has been used to observe flood-prone areas around the Dengkeng River and field observation was done in prone areas. The results showed that the Cawas sub-district tends to have the highest flooding potential due to the overflow of the Dengkeng River. On the other hand, the result of field observation showed sediments that settled in Tukuman Weir are dominated by coarse sand and gravel that tend to be influenced by the upstream in Merapi Volcano. Moreover, flood damage continues to occur as the consequences of riverbank erosion and high sedimentation at specific locations on the Dengkeng River.
\end{abstract}

Keywords River Model, Nays2DFlood, Flood, Field Observation

\section{Introduction}

Flood disaster often occurring in Indonesia causes material and non-material losses. Dengkeng River is a tributary of the Bengawan Solo River that experiences flooding every year. Dengkeng watershed is located among six regions, namely Klaten, Sukoharjo, Wonogiri, Sleman, Gunung Kidul, and Boyolali, where upstream of the river is located in Merapi volcano. In terms of economic aspects, Dengkeng River has a significant contribution to the sustainability of the agricultural business in the area traversed by this river [1]. The area of Dengkeng watershed is $822.153 \mathrm{~km}^{2}$, where more than $50 \%$ of the total area is very prone to flooding [2] [3]. Losses in agriculture due to floods that hit several sub-districts in Klaten Regency reached 2,338 hectares or around 7.3 billion rupiah (BPPD Klaten 2017). The main cause of the flooding is the severity of sedimentation and riverbank damage. Consequently, when heavy rainfall comes, the capacity of the river cannot accommodate the overflow. Dengkeng watershed areas are lowland areas with inappropriate land uses and have a type of lithosol soil with a reasonably low infiltration value; thus it is possible to create a pool of water that causes flooding [4]. Based on the previous study, climate change has occurred in the Dengkeng River as seen by the increase in temperature and rainfall which directly affect land use patterns, water availability, flood control performance, local social and economic development [5]. Moreover, human progresses such as urbanization and structural defences (e.g., levees, dams, sea walls) have a significant influence on the movement and severity of flooding, ameliorating impacts in some cases, but amplifying them in others [6]. Previous studies in Dengkeng River have produced one-dimensional river (1D) modelling and analyzed sedimentation rates from secondary data [7]. Therefore, flood simulation models are required to identify flood-prone areas. In this study, a two-dimensional (2D) river model using the International River Interface Cooperative (iRIC) Nays2DFlood software from Japan has been applied to observe flood-prone areas around the Dengkeng River. This model is able to simulate two-dimensional horizontal (2D) flow, sediment transport, morphological changes from bottom depth, and erosion in rivers. 


\section{Literature Review}

\section{Flood Risk Analysis \& Hazard Assessment}

There are many flood risk management methods can be applied to reduce destruction and manage flood risk. Proper estimation for flood risk is challenging and needs careful consideration of a number of factors, including watershed properties such as size, topography, and land use, etc. It is important to define which types of the flood are most common before a hazard assessment is implemented since, in most cases, the selection of hazard and risk modelling methods depend on that. The common concepts are valid for the other types of floods, while technical note focuses on fluvial floods. The objective of flood hazard assessment is to comprehend the probability that a flood of a particular intensity will happen over an extended time [8]. Hazard assessment intents to estimate this probability over periods of years to decades to contribute risk management activities. Intensity usually indicates a combination of flood depth and horizontal flood extent. Moreover, other intensity measures such as flow velocity and flood duration can also be important depending on the situation.

\section{iRIC Nays2DFlood}

Nays2DFlood is one of iRIC solver that is used for flood flow analysis developed by Professor Yasuyuki Shimizu from Hokkaido University. Nays2DFlood relies on unsteady 2-dimensional plane flow simulation by using boundary-fitted coordinates as the general curvilinear coordinates, which allows both channel banks and floodplain edges to be fitted to the coordinate system [9]. This solver has been applied for a flood flow analysis of rivers over a wide range of length scales, from small streams to the Mississippi. Nays2DFlood is also used for the flood process analysis of primitive rivers and rivers in developing countries because the solver does not require river channel data. This model has succeeded in simulating flooding in several countries, for example, flooding in the city of Kabul by using modified DEM data in 2016 [10].

\section{Model Equation}

The solver divides flow motion into two coordinate systems, namely the orthogonal coordinate system $(\mathrm{x}, \mathrm{y})$ and the curve linear coordinate system or moving boundary fitted coordinates.

Continuity Equation:

$$
\frac{\partial h}{\partial t}+\frac{\partial(h u)}{\partial x}+\frac{\partial(h v)}{\partial y}=0
$$

Momentum Equation:

In the $\mathrm{x}$ direction,

$$
\frac{\partial h}{\partial t}+\frac{\partial\left(h u^{2}\right)}{\partial x}+\frac{\partial(h u v)}{\partial y}=-\operatorname{gh} \frac{\partial H}{\partial x}+\frac{\tau_{x}}{\rho}+D^{x}+\frac{F_{x}}{\rho}
$$

With,

$$
\frac{\tau_{x}}{\rho}=C_{f} u \sqrt{u^{2}+v^{2}}
$$

$$
\begin{gathered}
D^{x}=\frac{\partial}{\partial x}\left[v_{t} h \frac{\partial u}{\partial x}\right]+\frac{\partial}{\partial y}\left[v_{t} h \frac{\partial u}{\partial y}\right] \\
\frac{F_{x}}{\rho}=\frac{1}{2} C_{D} a_{s} h_{v} u \sqrt{u^{2}+v^{2}}
\end{gathered}
$$

In the y direction,

$$
\frac{\partial(v h)}{\partial t}+\frac{\partial(h u v)}{\partial x}+\frac{\partial\left(h v^{2}\right)}{\partial y}=-g h \frac{\partial H}{\partial x}+\frac{\tau_{y}}{\rho}+D^{y}+\frac{F_{y}}{\rho}
$$

With,

$$
\begin{gathered}
\frac{\tau_{y}}{\rho}=C_{f} u \sqrt{u^{2}+v^{2}} \\
D^{y}=\frac{\partial}{\partial x}\left[v_{t} h \frac{\partial v}{\partial x}\right]+\frac{\partial}{\partial y}\left[v_{t} h \frac{\partial v}{\partial y}\right] \\
\frac{F_{y}}{\rho}=\frac{1}{2} C_{D} a_{s} h_{v} u \sqrt{u^{2}+v^{2}}
\end{gathered}
$$

Where, $h$ is water depth, $t$ is time, u average velocity of direction $\mathrm{x}, \mathrm{v}$ is flow velocity in the y-direction, $\mathrm{g}$ is an acceleration of gravity, $\mathrm{H}$ is an elevation of water level, $\tau \mathrm{x}$ is component of river bed shear stress direction $\mathrm{x}, \tau \mathrm{y}$ is component of river bed shear stress direction y. Details on the calculations are provided on the iRIC web page.

\section{Research Methodology}

\section{Type of Research}

This type of research is a quantitative descriptive study combining the results of numerical analysis of the Nays2DFlood software in Dengkeng River with the results of field observations in the form of Grain Size Analysis.

\section{Study Area}

The study area is located in Dengkeng River that is part of the Bengawan Solo River area, as shown in Figure 1 below. Administratively, the study area covers several regencies in Central Java province but the most extensive administrative area of the Dengkeng watershed is in Klaten Regency including the districts of Kemalang, Manisrenggo, Karangnongko, Jatinom, Tulung, Polaharjo, Delanggu, Karanganom, Kebon Arum, Jogonalan, Gantimwarno, Wedi, Bayat, Cawas, Trucuk, Pedak, Karangdowo, and Ceper. The area of Dengkeng watershed is $822.153 \mathrm{~km}^{2}$ where upstream of the river is located in Merapi volcano. Topographically Dengkeng watershed is at an elevation of $75-2000 \mathrm{~m}$ above sea level. The lowest height $(75-100 \mathrm{~m})$ is in Karangdowo Sub-district, and Cawas Sub-district and the highest elevation is in Mount Merapi (Pemalang and Musuk Sub-districts). Regarding the slope of the Dengkeng watershed, the majority are in the flat category, ranging from $0-8 \%$. In addition, the Dengkeng River is classified as a sloping surface flow pattern or (Mild) profile because the riverbed slope is higher than the critical slope [11]. The land use is dominated by rice fields (> 45\%), settlements $(25 \%)$, forests $(17 \%)$, dry land agriculture $(9 \%)$, and other land uses around $4 \%$.

In general, climatic conditions in the Dengkeng River are relatively similar to other regions in the Solo River, 
which is a wet tropical climate with the characteristics of the rainy and dry seasons. Winds from the southwest and northwest that usually blow in November to April result in the rainy season. While the dry season lasts from July to October caused by winds blowing from the south and southeast.

\section{Research Stages}

The method used in this study is a numerical analysis and field surveys as can be seen in the flowchart of Figure 2 below.

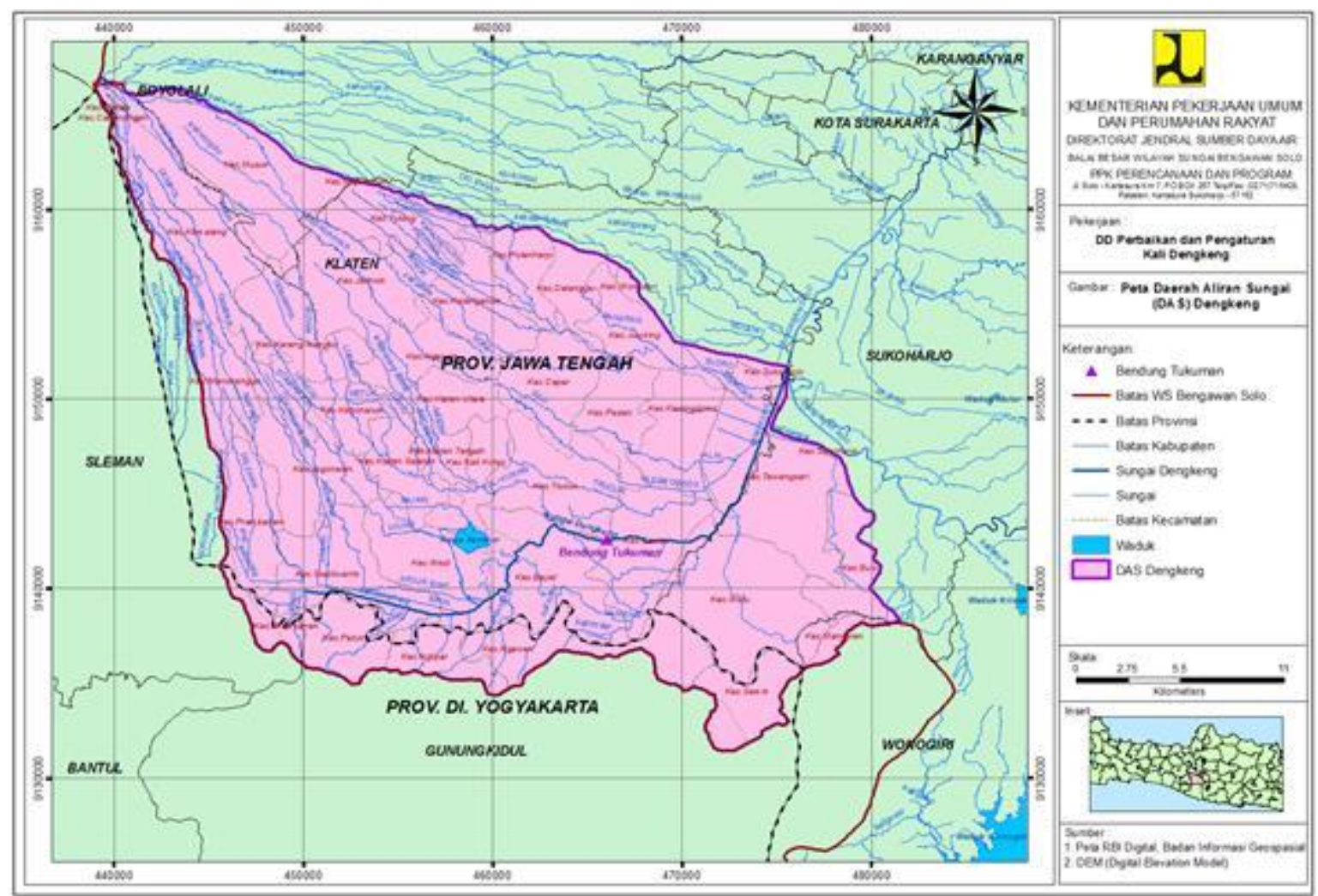

Figure 1. Dengkeng Watershed (Undip Disaster Study Center, 2017)

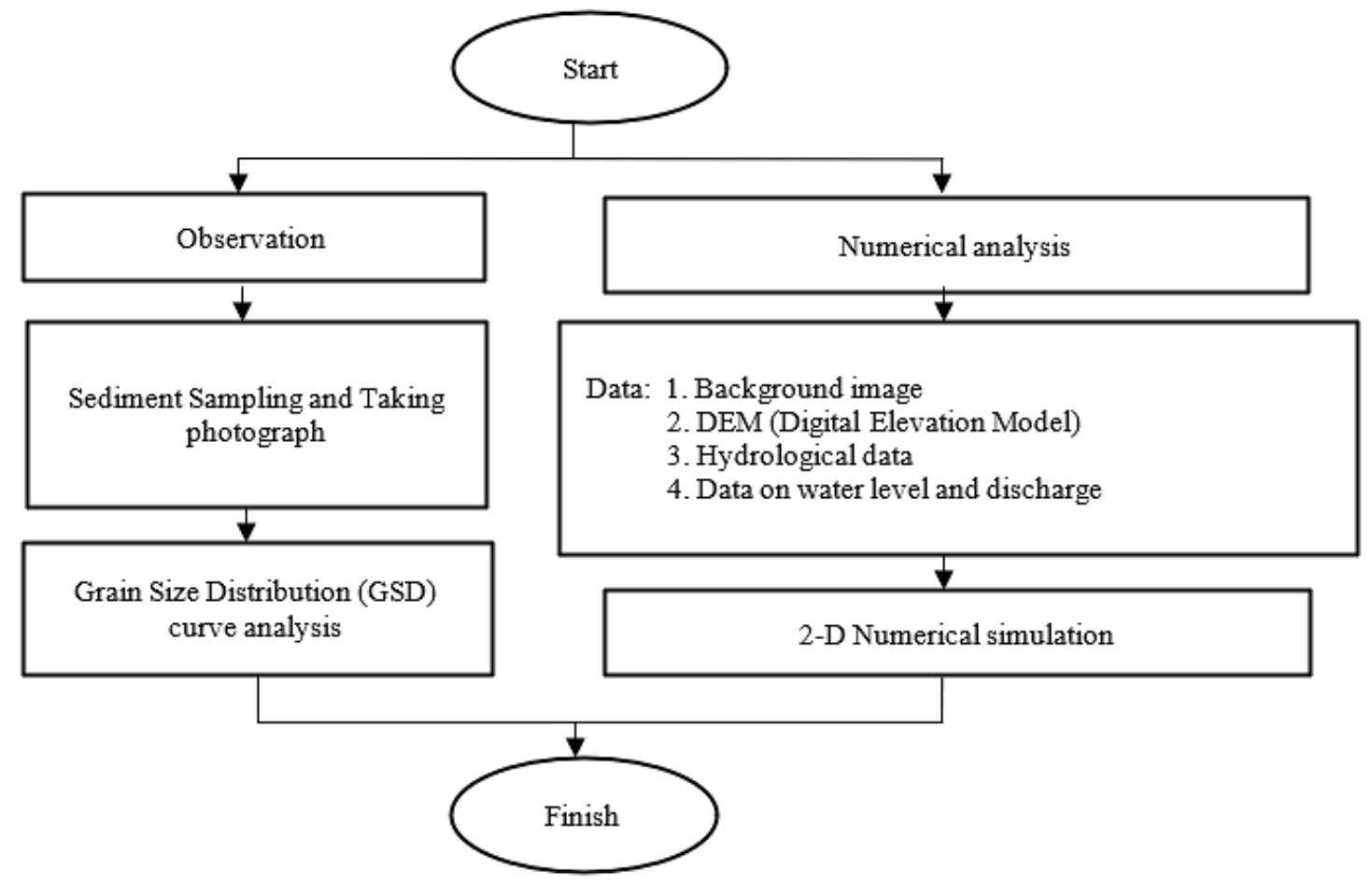

Figure 2. Research Stages 


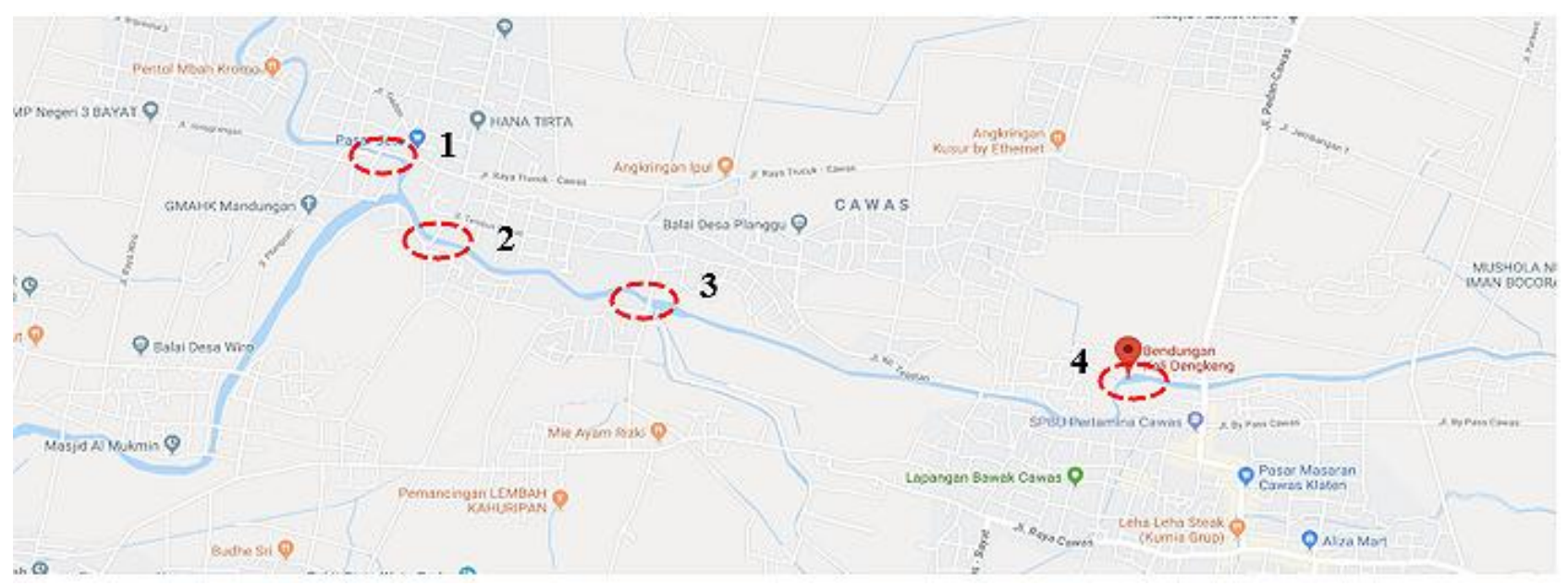

Figure 3. Location of field observation in Dengkeng River; (1) Jeto Weir, (2) Jembatan Tengah Weir, (3) Talang Weir, and (4) Tukuman Weir

The numerical analysis was used Nays2DFlood software including Dengkeng River in Klaten, Sukoharjo. Elevation data used is SRTM with Q5th discharge, and rain data used are from 2002 to 2016 from the nearest rainfall station on the Dengkeng River.

Based on a previous study in 2017, there are 67 riverbanks along the Dengkeng River in critical condition [12]. In this study, fieldwork was conducted at four points in the Klaten area, namely in Jeto Weir, Jembatan Tengah Weir, Talang Weir, and Tukuman Weir as seen in Figure 3. Tukuman Weir is a water structure located in Plosowangi village, Cawas sub-district, Klaten. This weir is used for irrigation needs in the village that irrigates around 280.8 hectares of the agricultural area [13]. Field observations were carried out by taking sediment samples at the location and measuring $10 \mathrm{~cm}$ into the sediment taken, as shown in Figure 4 and Figure 5 below. Besides, checking the condition of the river is done, including the condition of the river embankment and also the type of sediment that settles in the field. Furthermore, those samples from the observation site were brought to the Soil Mechanics Laboratory of Diponegoro University to examine grain size analysis.

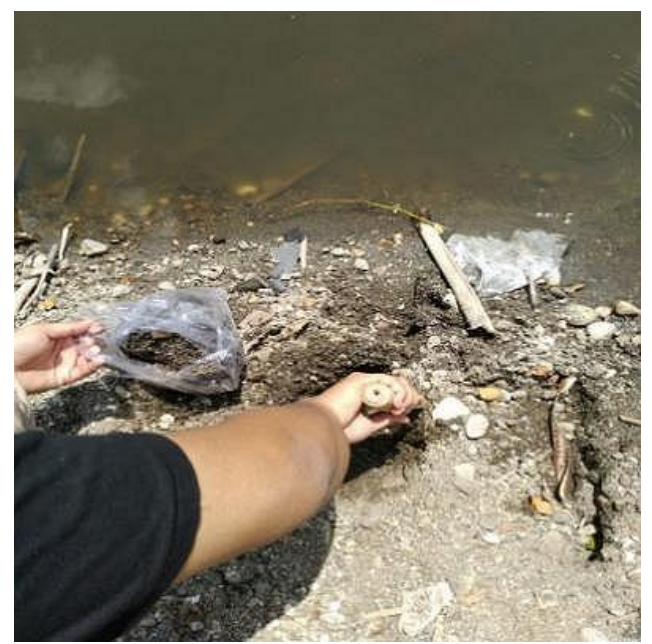

Figure 4. Taking a sediment sample in Dengkeng

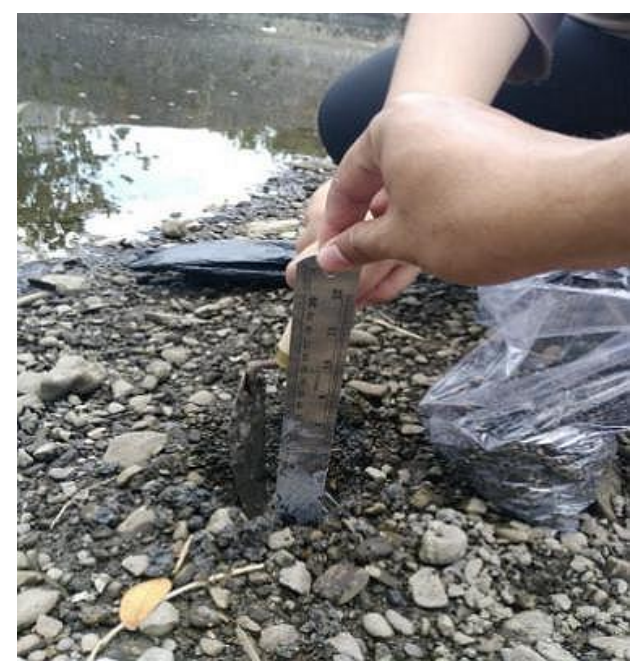

Figure 5. Measuring the high of sediment location

\section{Result and Discussion}

This area of the numerical simulation using Nays2DFlood is Dengkeng River which includes Klaten and Sukoharjo, Central Java, Indonesia. Some data were used in simulation, such as a base map, elevation data, flow discharge, and rainfall data.

The grid of Dengkeng River and The result of flood simulation from upstream to downstream can be seen in Figure 6. The simulation results are only in the form of the general area, and then ArcGIS 9.3 software is used to get specific inundation areas in Dengkeng River.

Based on the final analysis using ArcGIS 9.3, there are six areas affected by the flood that mostly come from Klaten district and follow Sukoharjo district that was showed in blue colour shown in Figure 7. As shown in Table 1, Cawas sub-district is the most prone area with inundation $43 \%$. On the other hand, the lowest number of inundation is from Trucuk sub-district $(0.976 \%)$. The previous flood in 2018 recorded that Cawas sub-district was the area most severely affected by flooding. 


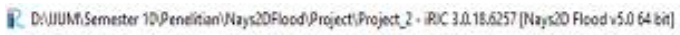

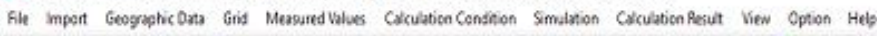

B

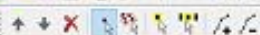

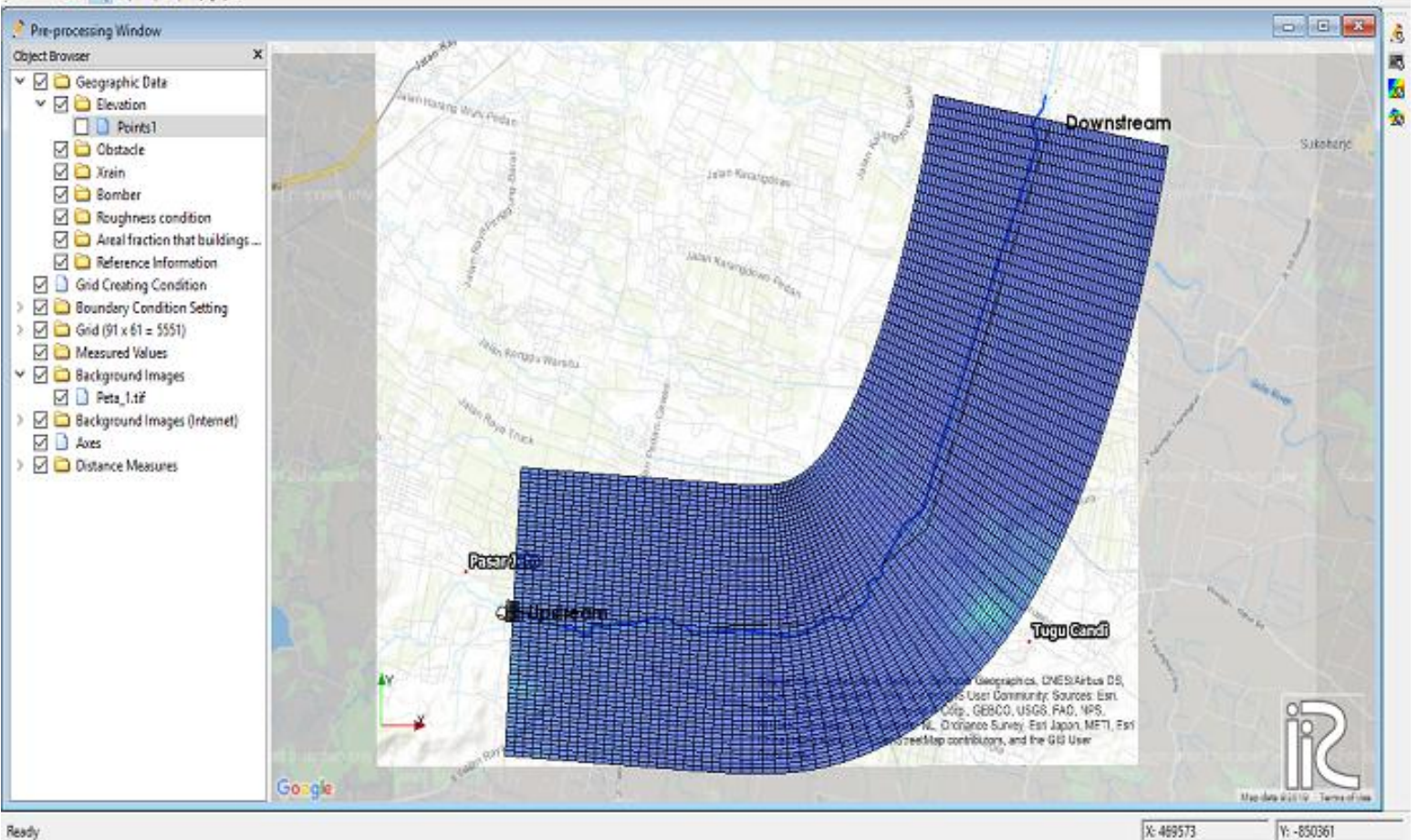

(a)

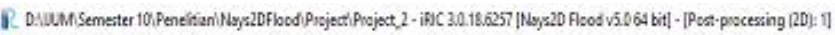

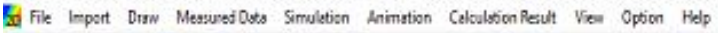

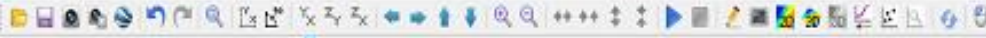

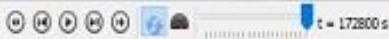
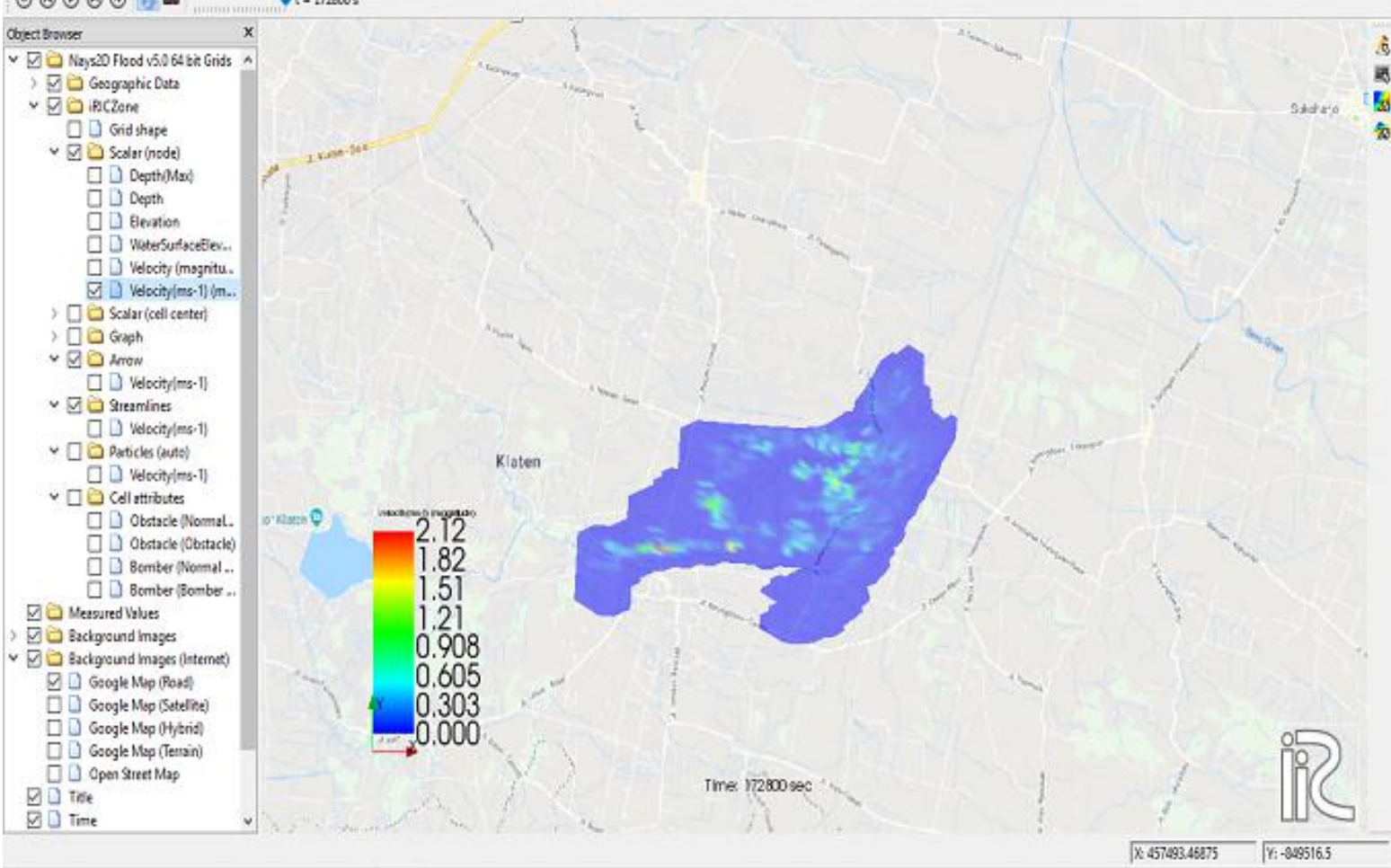

(b)

Figure 6. (a) Grid of river model and (b) Result of flood simulation 


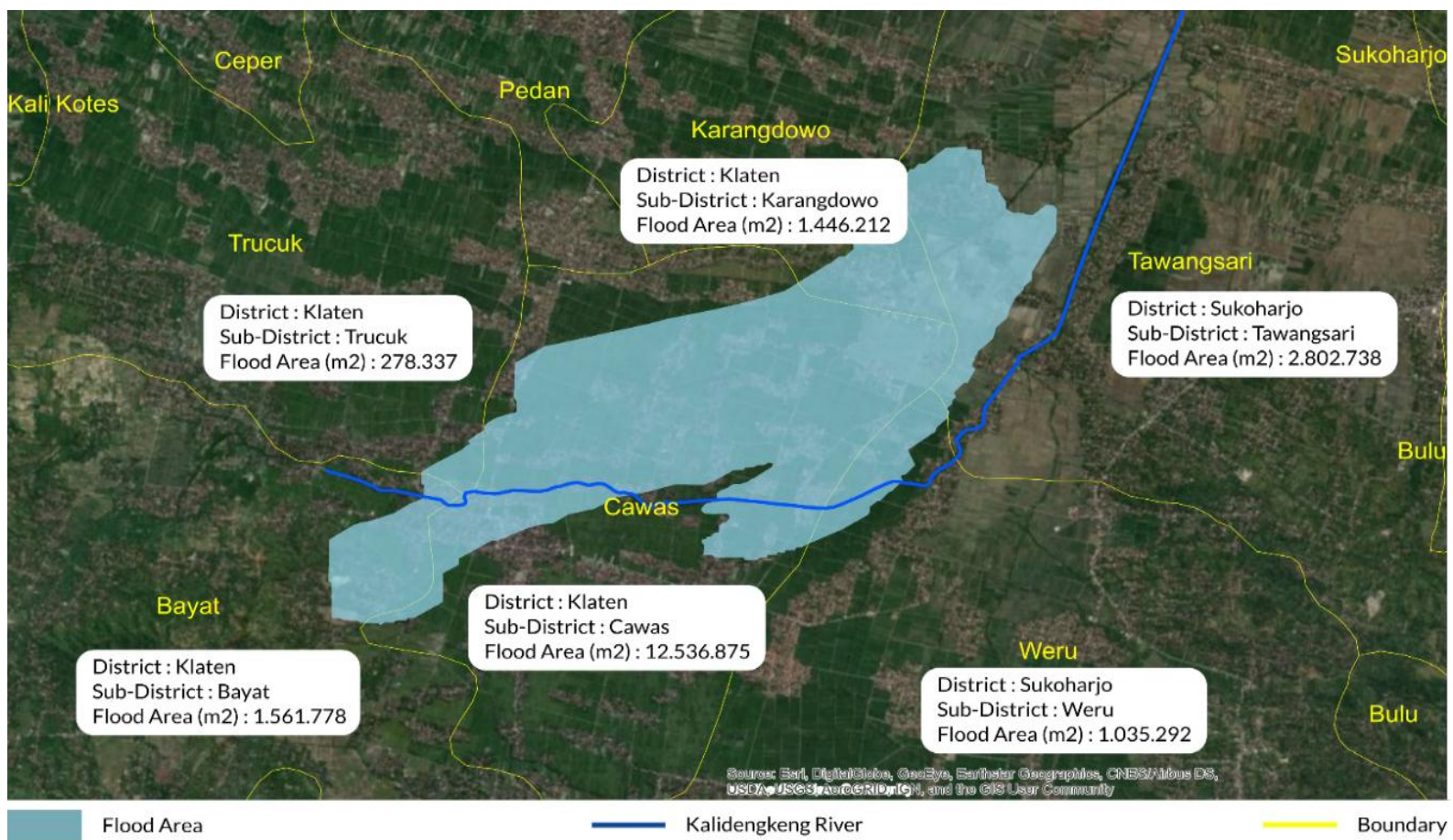

Figure 7. Affected area of flood simulation using ArcGIS software

Table 1. Inundation areas of Dengkeng River

\begin{tabular}{cccccc}
\hline \multirow{2}{*}{ No } & District & Sub-district & \multicolumn{3}{c}{ Area } \\
\cline { 4 - 6 } & & & Region $\left(\mathbf{m}^{2}\right)$ & Inundation Area $\left(\mathbf{m}^{2}\right)$ & \% \\
\hline 1 & Klaten & Bayat & 37812164 & 1561778 & 4.130 \\
2 & Klaten & Cawas & 28926514 & 12536875 & 43.340 \\
3 & Klaten & Trucuk & 28507481 & 278337 & 0.976 \\
4 & Klaten & Karangdowo & 21550213 & 1446212 & 6.711 \\
5 & Sukoharjo & Weru & 45759413 & 1035292 & 2.262 \\
6 & Sukoharjo & Tawangsari & 56049814 & 2802738 & 5.000 \\
\hline
\end{tabular}

Field observation was carried out in areas where flooding frequently occurs each year. Observations were made in the dry season of August 2019. As shown in Figure $8 \mathrm{a}$, the water level tends to be low in the dry season, resulting in a lot of sedimentary deposits in Jeto weir. Around Jeto Weir is dominated by tree debris where there are many trees around the river that are vulnerable to dropping their branches. In addition, Figure $8 \mathrm{~b}$ shows that there is a lot of household waste accumulated near the gate of Tukuman Weir with a low water level.

Not only household waste, but also around Tukuman Weir has a sedimentary deposit on the riverside and middle of the Dengkeng River as shown in Figure 9a. Moreover, Riverbank in the Tukuman Weir tends to spills the material into the river because it will be destroyed by the seasonal flood, as shown in Figure 9b. In some places, the condition of the Dengkeng riverbank is quite steep, and the soil conditions are relatively soft. In terms of river classification, Dengkeng River is classified as a river that tends to be straight but is dynamic in nature with considerable potential for change. There are several structures across the river, both weirs, and bridges. The existence of a weir has a dual function namely irrigation and detaining erosion. Some river segments have been installed riverbank protectors with stone pairs. The physical condition of Dengkeng river water is relatively better and clearer compared to other rivers in the Solo. This situation can occur because the upstream of the river originates from Mount Merapi, and there are fewer pollutants entering the water. 


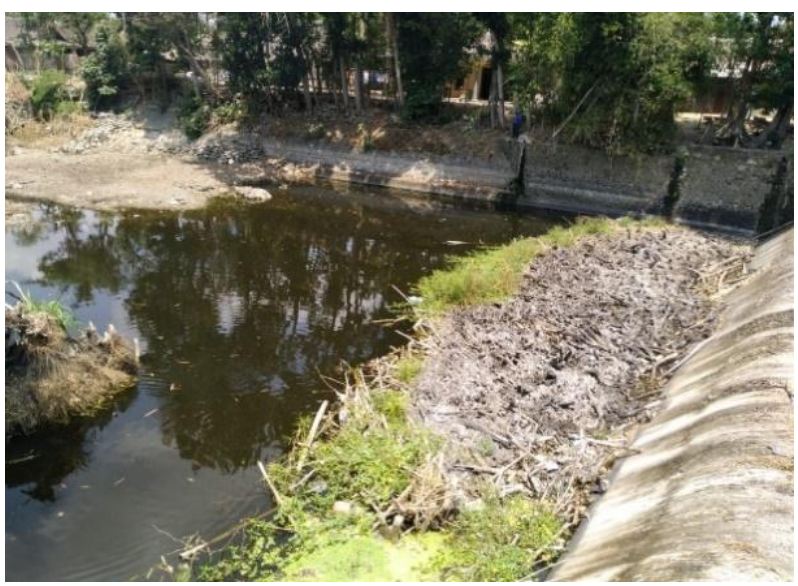

(a)

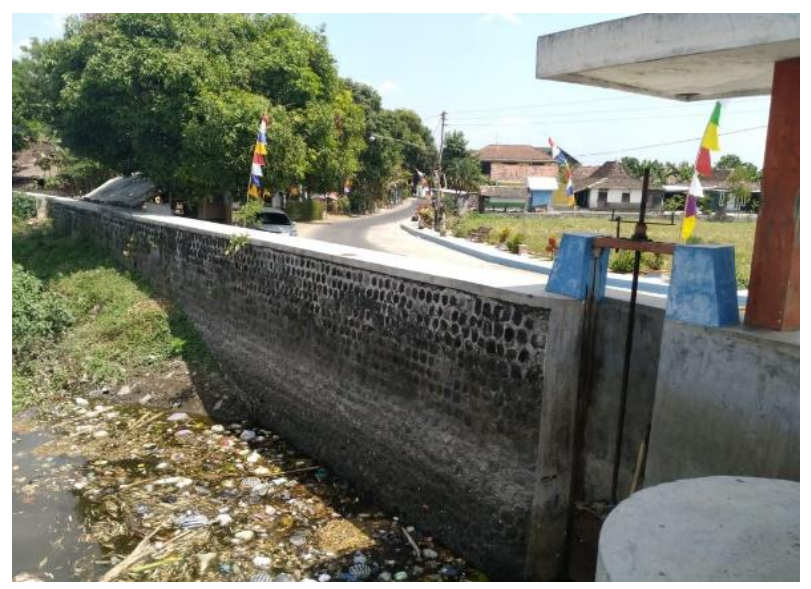

(b)

Figure 8. (a) Tree debris in Jeto Weir and (b) Household waste in Tukuman Weir

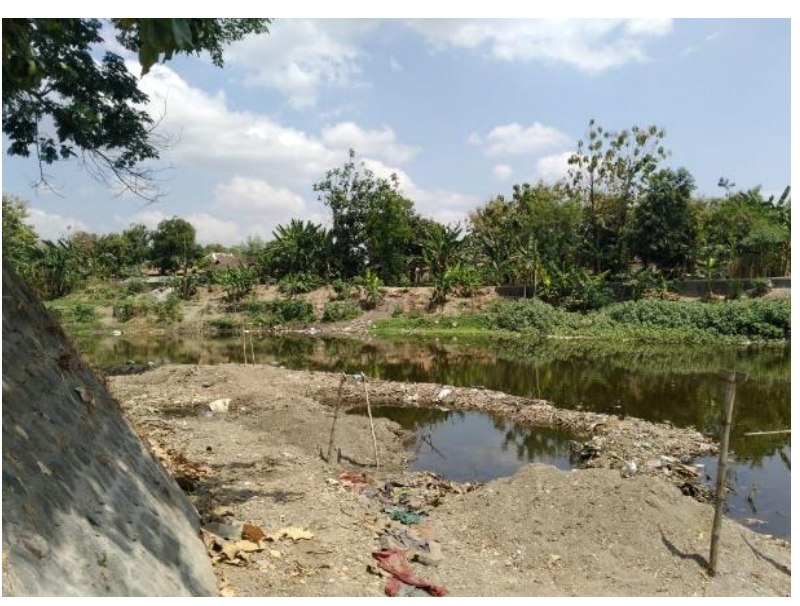

(a)

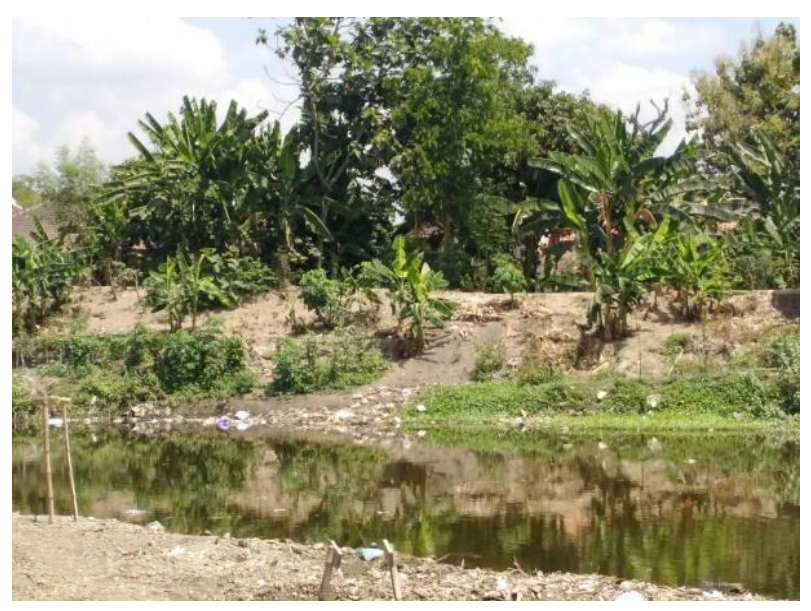

(b)

Figure 9. (a) Sedimentary deposit in Tukuman Weir and (b) Riverbank of Tukuman Weir

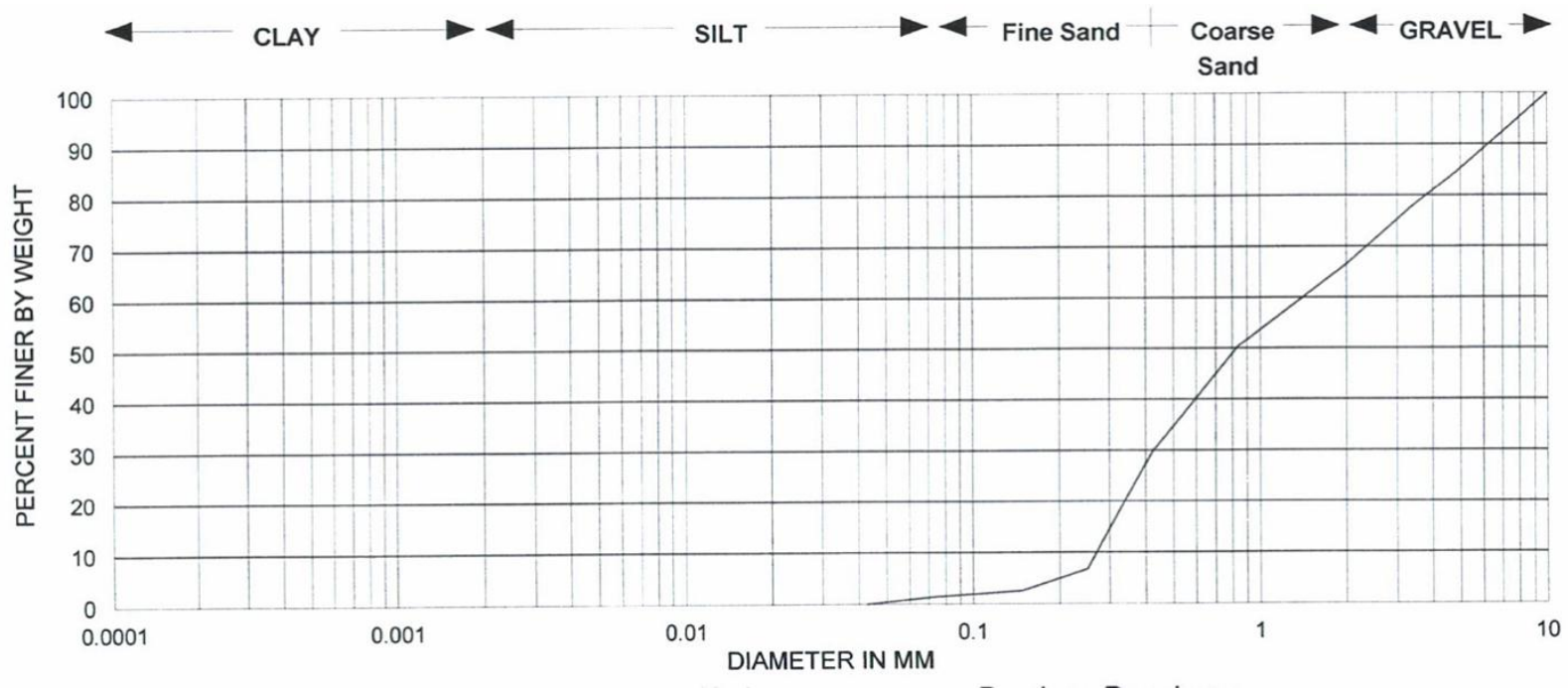

Figure 10. Grain Size Distribution in Tukuman Weir 
The result of the field observation is shown in Figure 10. It represents Grain Size Distribution in Tukuman Weir. It shows that coarse sand has $36.89 \%$ of sediment and gravel has $33.54 \%$ of sediment. Then, fine sand has $28.19 \%$, and silt has a small amount of sediment, $1.38 \%$. At the same time, clay is not found at the field observation. From this result, we assume that a high amount of gravel and coarse sand tend be found in most parts of the inundation area. The upstream of the Dengkeng River is located on Merapi volcano, thus making sediments that settle in the Dengkeng River tend to be brought from the mountain.

\section{Conclusions and Suggestion}

This research presented the situation of the affected area by using numerical simulation and field observation. The result of numerical simulation showed flood inundation mapping, which has a tendency to predict real flood condition in Dengkeng River, makes Cawas sub-district is the most potential area for flooding. On the other hand, field observation showed sediments settled in Tukuman Weir are dominated by coarse sand and gravel. Sediment characteristics in the Dengkeng River tend to be influenced by the upstream of the river, which is located on the Merapi Volcano and sudden flash flood. By conducting research with two dimensions and field research, it is hoped that it will add a reference for flood mitigation and prevention in the Dengkeng Watershed, thus saving millions of dollars in investments. Other issues, penalties for dumping garbage in the river should be re-affirmed because there is a lot of household waste around the Dengkeng River, making the river loses its capacity. Although the simulation is successfully performed, it just roughly described the flood phenomena in Dengkeng River. Therefore, improving the research is needed to predict the situation of a flood near to the real situation.

\section{REFERENCES}

[1] Maridi, M \& Marjono, M. (2013). Kontribusi Keanekaragaman Vegetasi untuk Memelihara Keberlanjutan Kualitas Tebing Daerah Aliran Sungai Dengkeng di Wilayah Solo Raya Jawa Tengah. Seminar Nasional X Pendidikan Biologi FKIP UNS, 5049.

[2] Ratnasari, D., \& Kusumandari, E. (2017). TINGKAT KERAWANAN BANJIR DI SUB DAS DENGKENG DAS BENGAWAN SOLO. Skripsi S1 Program Studi Kehutanan $U G M$.
[3] Aurdin, Yulyana. (2014). Pengaruh perubahan tataguna lahan terhadap karakteristik hidrograf banjir (studi kasus DAS Dengkeng dan DAS Jlantah Bagian Hulu Bengawan Solo Kabupaten Sukoharjo, Provinsi Jawa Tengah). Jurnal Tekno Global Fakultas Teknik UGM, III(1), 1-13. Retrieved from http://eprints.uigm.ac.id/13/1/Jurnal\%20Penelitian\%2 OYulyana\%20Aurdin\%200210078401.pdf

[4] Aji, M.D.N., Sudarsono B., \& Sasmito, B. (2014). Identifikasi Zona Rawan Banjir Menggunakan Sistem Informasi Geografis (Studi Kasus: Sub DAS Dengkeng). Jurnal Geodesi Undip, 3(1). Retrieved from https://ejournal 3.undip.ac.id/index.php/geodesi/article/view/4708

[5] Sarminingsih, A., Handayani, D., Sutrisno, E., \& Zaman, B. (2018). Evaluation the Water Availability in the Dengkeng River Due To Landuse and Climate Changes. E3S Web of Conferences, 73, 03008. doi:https://doi.org/10.1051/e3scon $\mathrm{f} / 20187303008$

[6] Rufat, S., Tate, E., Burton, C., \& Maroof, A. (2015). Social vulnerability to floods: Review of case studies and implications for measurement. International Journal of Disaster Risk Reduction, 14, 470-486. doi:https://doi.org/10 .1016/j.ijdrr.2015.09.013

[7] Rai, Pawan., C T, Dhanya., \& Chahar, B. (2018). Coupling of 1D models (SWAT and SWMM) with 2D model (iRIC) for mapping inundation in Brahmani and Baitarani river delta. Natural Hazards, 92, 1821-1840. doi:https://doi.org/ 10.1007/s11069-018-3281-4

[8] Wright, D.B. (2015). Methods in Flood Hazard and Risk Assessment [web page]. Retrieved from https://www.preve ntionweb.net/files/51114_capramethodsinfloodhazardandris kass.pdf

[9] Admin. (2020). Nays2DFlood [web page]. Retrieved from https://i-ric.org/en/solvers/nays2dflood/

[10] Shokory, J.A.N., Tsutsumi, J., \& Sakai, K. (2016). Flood Modeling and Simulation using iRIC: A Case Study of Kabul City. E3S Web of Conferences, 7, 04003. doi: https:// doi.org/10.1051/e3sconf/20160704003

[11] Fauziyah, A.L., Suyanto, S., \& Muttaqien, A.Y. (2015). ANALISIS POLA ALIRAN PERMUKAAN SUNGAI DENGKENG MENGGUNAKAN HYDROLOGIC ENGINEERING CENTER - RIVER ANALYSIS SYSTEM (HEC-RAS). MATRIKS TEKNIK SIPIL UNS, 127. doi:https://doi.org/10.20961/mateksi.v3i1.37318

[12] Kominfo. (2018). HASIL SURVEI SUNGAI DENGKENG, ADA BEBERAPA YANG PERLU PERBAIKAN [web page]. Retrieved from https://klatenkab.go.id/hasil-surve-su ngai-dengkeng-ada-beberapa-yang-perlu-perbaikan/

[13] Indhillahi, Muhamad. (2012). ANALISIS PROFIL MUKA AIR PADA BENDUNG TUKUMAN DI SUNGAI DENGKENG KECAMATAN CAWAS KABUPATEN KLATEN. Proyek Akhir Prodi Teknik Sipil Fakultas Teknik Universitas Negeri Yogyakarta. 